\title{
Teknik Pengamatan Sampel Biologi dan Non-konduktif Menggunakan Scanning Electron Microscopy
}

\author{
1,2Damar Rastri Adhika*), 2Atsarina Larasati Anindya, 2Viny Veronika Tanuwijaya \& 2,3Heni Rachmawati \\ 1 Program Studi Teknik Fisika, Institut Teknologi Bandung, Bandung, Indonesia \\ 2Pusat Penelitian Nanosains dan Nanoteknologi, Institut Teknologi Bandung, Bandung, Indonesia \\ ${ }^{3}$ Kelompok Keilmuan Farmasetika, Sekolah Farmasi, Institut Teknologi Bandung, Bandung, Indonesia
}

(corresponding author) damar@tf.itb.ac.id *)

\begin{abstract}
Abstrak
Scanning electron microscope (SEM) banyak dimanfaatkan untuk mengamati struktur morfologi permukaan sampel dalam perbesaran yang tinggi dengan menggunakan berkas elektron berenergi tinggi. Pengamatan berbagai jenis material dengan beragam karakter dan properti fisis yang berbeda dapat dilakukan menggunakan SEM, namun tentu saja diperlukan pertimbangan dan pendekatan yang khusus untuk setiap jenis sampel yang berbeda agar pengamatan menggunakan SEM dapat dilakukan serta mampu memberikan hasil pengamatan SEM dengan kualitas yang baik dan mampu memberikan informasi keadaan struktur sampel yang sebenarnya. Pembahasan dalam makalah ini akan berfokus pada teknik-teknik khusus yang perlu ditempuh dalam melakukan pengamatan sampel biologi menggunakan SEM yang relatif lebih sulit untuk dilakukan daripada pengamatan sampel konduktif seperti logam. Pengamatan SEM dilakukan dalam kondisi vakum yang tinggi sehingga cukup sulit untuk mengamati sampel biologi yang secara alami memiliki kandungan air yang tinggi dan memiliki struktur yang rapuh karena memiliki banyak pori didalamnya. Selain itu penembakan berkas elektron secara terus menerus pada permukaan sampel membuat sampel biologi menjadi bermuatan negatif karena elektron terlalu banyak tersimpan pada sampel dan tidak dapat dialirkan keluar karena sifat sampel biologi yang tidak konduktif. Beberapa teknik preparasi, pengaturan nilai parameter pengamatan, dan beberapa jenis SEM yang dapat digunakan untuk mengamati sampel-sampel biologi dan non-konduktif akan dibahas disini.
\end{abstract}

Kata Kunci: SEM, teknik preparasi, sampel biologi, sampel non-konduktif

\section{Pendahuluan}

Mikroskop adalah alat bantu yang digunakan untuk mengamati benda-benda kecil yang tidak dapat dilihat dengan mata. Mikroskop yang paling umum digunakan adalah mikroskop cahaya yang memanfaatkan berkas cahaya tampak dan lensa optik. Batas resolusi dari mikroskop cahaya dibatasi oleh panjang gelombang cahaya tampak yang digunakan yaitu setengah dari panjang gelombang, sesuai dengan teori Abbe ${ }^{[1]}$ yang dapat dilihat di persamaan (1), dimana $\lambda$ adalah panjang gelombang dan NA adalah numerical aperture. Untuk meningkatkan batas resolusi maka dikembangkan mikroskop elektron dimana panjang gelombang berkas elektron dapat diatur dengan mengubah nilai tegangan akselerasi yang diberikan ${ }^{[1]}$ ketika membangkitkan berkas elektron sesuai dengan persamaan (2), dimana $\lambda$ adalah panjang gelombang dan $\mathrm{E}$ adalah energi akselerasi.

$$
\begin{aligned}
& d=\frac{\lambda}{2(N A)} \\
& \lambda=\frac{1.22}{E^{1 / 2}}
\end{aligned}
$$

Terdapat dua jenis mikroskop elektron yaitu scanning electron microscope (SEM) dan transmission electron microscope (TEM). SEM digunakan untuk mengamati morfologi permukaan sampel dalam perbesaran tinggi sementara TEM digunakan untuk mengamati struktur internal sampel dalam perbesaran yang tinggi. Perbedaan fungsi ini menyebabkan perbedaan cara mempersiapkan sampel untuk SEM dan TEM. Perbedaan mendasar adalah sampel TEM harus dapat ditembus oleh berkas elektron sehingga harus sangat tipis yaitu disarankan pada ketebalan dibawah 100nm[2]. Untuk dimensi sampel SEM hanya dibatasi oleh ukuran bilik sampel dari alat SEM itu sendiri karena sampel tidak harus ditembus oleh berkas elektron. Komponen-koponen utama dari SEM diantaranya adalah electron gun yang berfungsi untuk membangkitkan berkas elektron, beberapa lensa elektromagnetik untuk mengkondisikan berkas elektron, serta detektor untuk beberapa jenis berkas yang berbeda. Berkas elektron yang sampai ke sampel akan berinteraksi dengan sampel dan menghasilkan beberapa jenis berkas 
yang berbeda seperti secondary electron (SE), backscattered electron (BSE), dan characteristic $x$ ray[1]. SE dan BSE adalah berkas yang digunakan untuk mendapatkan citra SEM.

Agar berkas elektron dapat mencapai sampel dengan optimal maka mikroskop elektron dioperasikan dalam keadaan vakum. Sampel biologi memerlukan penanganan khusus sebelum diamati menggunakan mikroskop elektron karena mikroskop bekerja dalam keadaan vakum sementara sampel biologi mengandung cairan, memiliki ikatan yang lemah, serta pada umumnya memiliki banyak rongga udara.

Karena berkas elektron akan terus menerus menumbuk sampel maka akan ada kelebihan elektron pada sampel yang akan dibuang melalui conductive tape ke sample stage kemudian ke ground. Apabila sampel tidak konduktif maka kelebihan elektron akan sulit terbuang dari permukaan sampel sehingga akan memperburuk kualitas citra SEM. Oleh karena itu perlu diterapkan beberapa cara untuk menangani sampel yang tidak konduktif yang akan dibahas dalam makalah ini. Selain itu juga dikembangkan beberapa teknik khusus untuk pengamatan sampel biologi yang akan sedikit dibahas disini.

\section{Metoda, Hasil, dan Diskusi}

Tahapan persiapan sampel sebelum diamati dengan SEM sangat penting untuk bisa mendapatkan hasil pengamatan yang berkualitas serta untuk bisa memberikan analisis yang tepat. Seluruh perlakuan yang diberikan pada saat persiapan sampel tidak boleh merubah struktur asli dari sampel tersebut agar hasil pengamatan SEM merepresentasikan struktur asli dari sampel.

Tahapan utama preparasi sampel biologi sebelum diamati menggunakan SEM adalah pemotongan sampel dengan orientasi yang diinginkan, fiksasi, dehidrasi, pengeringan, serta melapisi dengan lapisan konduktif. Tahapan fiksasi dilakukan untuk menjaga struktur asli dari sampel agar tidak mudah kempis atau hancur. Fiksasi yang umumnya dilakukan memiliki dua tahap yaitu tahapan pertama menggunakan glutaraldehyde ditambah dengan cacodylate buffer kemudian tahapan kedua adalah menggunakan osmium tetroxide pada buffer ${ }^{[3]}$. Dehidrasi bertujuan untuk menghilangkan kandungan air dari sampel. Dehidrasi dilakukan dengan proses perendaman dalam alkohol dengan tingkat konsentrasi yang bertambah secara bertahap hingga mencapai 100\%. Pengeringan biasanya dilakukan menggunakan critical point drying $(\mathrm{CPD})^{[4]}$ atau mengaplikasikan bahan kimia tertentu seperti hexamethyldisilazane ${ }^{[5]}$ yang bertujuan untuk menghilangkan kandungan cairan dari sampel tanpa membuat sampel menjadi kempis[6]. Pelapisan dengan material konduktif dapat dilakukan menggunakan sputtering machine dengan material konduktif yang digunakan pada umumnya adalah $\mathrm{C}, \mathrm{Au}, \mathrm{Pt}$. Pengamatan terhadap beberapa jenis sampel yaitu sampel konduktif, sampel biologi tanpa dan dengan preparasi, serta sampel biologi yang diamati dengan mode pengamatan khusus yaitu variable pressure (VP)SEM akan dibahas disini. Pengamatan dilakukan menggunakan SEM Hitachi SU3500 yang ada di pusat penelitian nanosains dan nanoteknologi (PPNN) ITB.

\subsection{Pengamatan sampel konduktif}

Untuk pengamatan sampel konduktif tidak dibutuhkan tahapan preparasi khusus, hanya membersihkan sampel tersebut dari debu kemudian menempelkannya pada sample stage menggunakan conductive tape seperti carbon atau copper tape untuk memudahkan kelebihan elektron pada sampel untuk dialirkan menuju ground. Contoh hasil pengamatan sampel konduktif dapat dilihat pada Gambar 1.

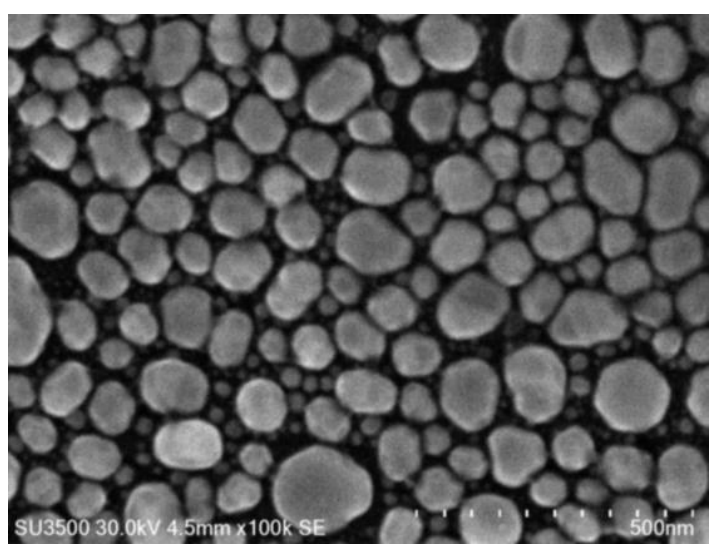

Gambar 1. Citra SEM dari nanopartikel emas

Hasil pengamatan nanopartikel emas tersebut menunjukkan bahwa untuk sampel konduktif pengamatan dapat dilakukan dalam energi akselerasi yang cukup tinggi yaitu $30 \mathrm{kV}$ dan dengan perbesaran yang tinggi yaitu 100.000 kali tanpa menimbulkan efek charging dan kerusakan pada sampel. Untuk pengamatan sampel nonkonduktif maka semakin tinggi perbesaran dan energi akselerasi akan meningkatkan efek charging[7]. Selain itu untuk sampel biologi yang memiliki ikatan lemah maka pengamatan dengan energi akselerasi dan perbesaran yang semakin tinggi akan lebih mudah menimbulkan kerusakan pada sampel. 


\subsection{Pengamatan sampel biologi dan non- konduktif tanpa preparasi sampel}

Hasil pengamatan SEM pada selembar mahkota bunga tanpa melakukan tahapan preparasi dapat dilihat pada Gambar 2. Dapat dilihat dari gambar tersebut bahwa terdapat distribusi gelap terang yang tidak merata dimana pada bagian yang sangat terang terjadi efek charging dimana penembakan elektron yang terus menerus menyebabkan terlalu banyak elektron pada permukaan sampel non-konduktif yang tidak dapat dialirkan ke ground. Perlu diperhatikan bahwa gambar ini diambil pada energi akselerasi $15 \mathrm{kV}$ dan perbesaran 1500 kali yang nilainya jauh lebih rendah daripada yang diberikan ketika mengambil gambar 1 untuk nanopartikel emas, namun untuk sampel non-konduktif, efek charging sudah sangat terlihat pada nilai energi akselersi dan perbesaran yang relatif rendah ini. Selain itu sampel yang diamati kelihatan berkerut pada gambar, kondisi ini disebebkan karena tanpa preparasi sampel yang tepat maka sampel biologi mudah mengalami kerusakan yaitu karena strukturnya yang rapuh dan banyak rongga udara, maka ketika diamati dalam keadaan vakum, struktur tersebut tidak dapat bertahan sehingga menjadi kempis atau hancur.

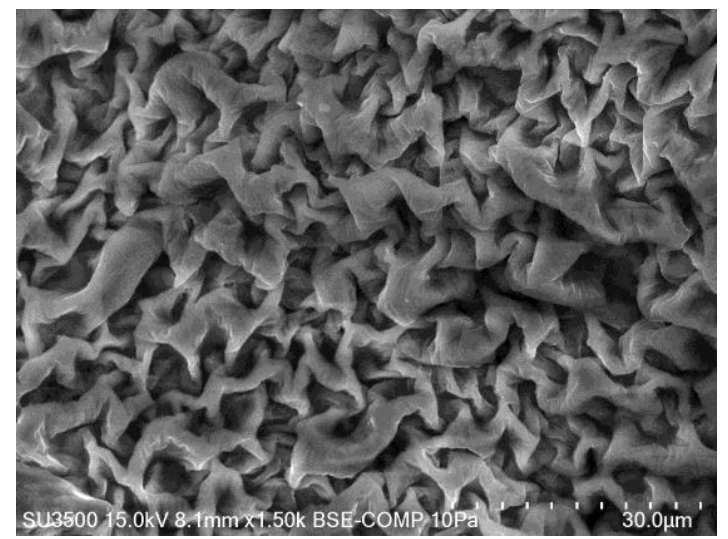

Gambar 2. Citra SEM dari mahkota bunga tanpa preparasi khusus

\subsection{Pengamatan sampel biologi setelah melakukan preparasi sampel}

Pengamatan SEM dilakukan terhadap sampel kolon tikus yang menderita inflamasi kolon sebelum dan setelah diobati seperti yang dapat dilihat pada Gambar 3. Tahapan preparasi yang dilakukan pada sampel ini adalah fiksasi menggunakan formalin, dehidrasi, dan paraffin embedding. Sampel yang telah ditanam dalam paraffin kemudian disayat menggunakan mikrotom dengan ketebalan akhir sampel adalah
$3 \mu \mathrm{m}$, kemudian sayatan diletakkan diatas cover glass. Selanjutnya dilakukan deparafinasi[8] terhadap sayatan tersebut yaitu melakukan pencucian dengan xylene pada $37^{\circ} \mathrm{C}$ selama $4 \times 30$ menit. Setelah itu sampel dicuci menggunakan ethanol $100 \%$ pada suhu ruang selama $4 \times 15$ menit. Sampel kemudian dibiarkan semalam pada suhu ruang agar kering. Sebeum diamati dengan SEM, sampel direkatkan dengan carbon tape pada sample stage kemudian dilapisi dengan lapisan konduktif yaitu lapisan emas menggunakan ion sputtering machine.
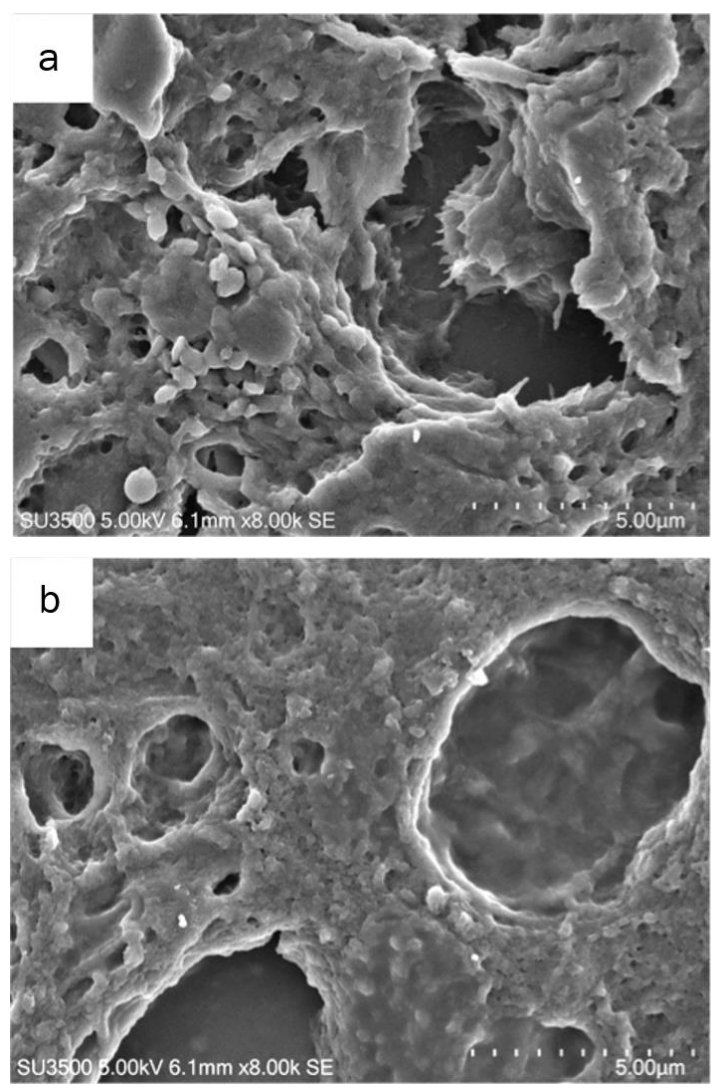

Gambar 3. Citra SEM sampel kolon tikus yang telah melewati tahapan preparasi yaitu sampel kolon tikus (a) sebelum diobati (b) setelah diobati.

Pengamatan SEM dilakukan terhadap sampel kolon tikus yang menderita inflamasi kolon menunjukkan perbedaan morfologi yang cukup signifikan pada kolon sebelum dan setelah diobati dimana kolon yang belum diobati pada gambar 3(a) menunjukkan banyak kerusakan pada jaringan dibandingkan dengan kolon yang sudah diobati pada gambar 3(b). Dari pengamatan ini dapat diketahui bahwa obat yang diberikan telah dapat bekerja dengan baik dalam mengatasi inflamasi kolon. Untuk jenis pengamatan seperti ini perlu dilakukan tahapan preparasi sampel yang 
benar agar kerusakan jaringan yang diamati menggunakan SEM adalah benar-benar kerusakan yang disebabkan oleh penyakit atau perlakuan tertentu yang diberikan, bukan kerusakan disebabkan oleh kesalahan preparasi sampel sebelum pengamatan SEM.

\subsection{Beberapa jenis SEM yang dikembangkan untuk pengamatan sampel non-konduktif dan biologi}

Pengembangan SEM dari sisi instrumen telah banyak dilakukan untuk memudahkan pengamatan sampel konduktif dan sampel biologi seperti cryo-SEM[9] dan VP-SEM. Penambahan cryo-chamber pada SEM memungkinkan pengamatan sampel SEM dalam keadaan beku karena pada cryo-chamber akan dialirkan nitrogen cair secara kontinu yang menjaga sampel agar tetap beku. Menjaga sampel dalam keadaan beku memungkinkan pengamatan sampel biologi tanpa perlu didahului dengan tahapan preparasi seperti fiksasi dan dehidrasi.

Sementara untuk mode VP-SEM dilakukan pada kondisi vakum yang lebih buruk daripada kondisi vakum pengamatan SEM standar. Kondisi vakum pada pengamatan SEM standar untuk SEM yang menggunakan filamen tungsten sebagai electron gun adalah $10^{-5}$ torr atau sekitar $1.5 \times 10^{-3}$ $\mathrm{Pa}^{[1]}$. SEM yang digunakan pada studi kali juga dilengkapi dengan mode VP-SEM dengan nilai tekanan yang dapat diatur pada rentang 10 - 650 Pa dimana nilai ini menunjukkan kondisi vakum yang lebih buruk daripada kondisi vakum untuk pengamatan SEM standar. Pada mode VP-SEM, udara dimasukkan ke dalam sample chamber sehingga kondisi vakum semakin buruk. Molekul udara di dalam chamber SEM akan terionisasi kemudian ion-ion positif akan tertarik ke permukaan sampel yang kelebihan elektron sehingga membantu mengurangi efek charging ketika mengamati sampel-sampel non-konduktif.

Pengamatan dengan mode VP-SEM dilakukan terhadap sampel serbuk sari yang dapat dilihat pada Gambar 4. Sampel serbuk sari diamati tanpa melalui tahapan preparasi sampel biologi dan juga tanpa penambahan lapisan konduktif. Pengamatan dilakukan pada kondisi vakum $10 \mathrm{~Pa}$, tegangan akselerasi $10 \mathrm{kV}$, serta perbesaran 2000 kali. Hasil pengamatan menunjukkan gambar SEM yang baik tanpa adanya efek charging akibat penggunaan mode VP-SEM.

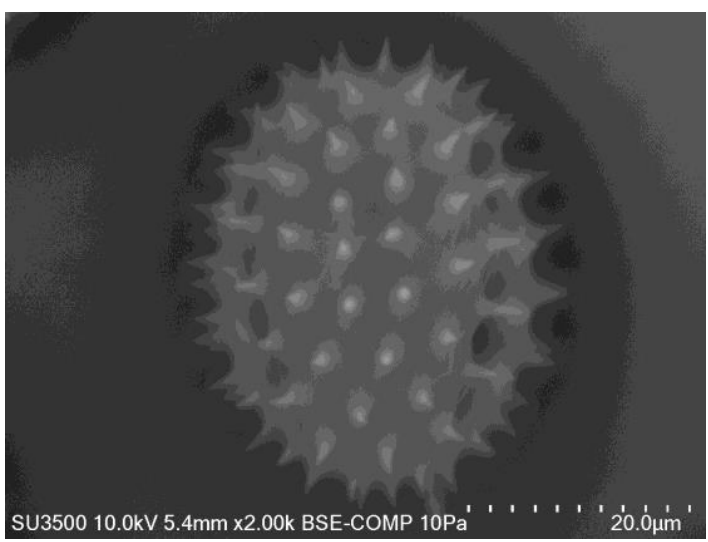

Gambar 4. Hasil VP-SEM untuk sampel serbuk sari tanpa tahapan preparasi.

\section{Kesimpulan}

Mikroskop elektron digunakan untuk mengamati benda dengan resolusi yang tinggi yaitu melebihi batasan resolusi dari mikroskop optik. Dalam proses pengamatan menggunakan mikroskop elektron diperlukan teknik preparasi khusus untuk mengkondisikan sampel agar sesuai dengan spesifikasi alat. Khususnya untuk pengamatan sampel biologi diperlukan sejumlah preparasi khusus agar dapat mengamati sampel sesuai dengan kondisi aslinya. Hal ini dikarenakan bahwa sampel biologi memiliki ikatan yang lemah, struktur yang rapuh karena pada umumnya berongga, serta memiliki kandungan air yang tinggi. Tahapan umum preparasi sampel biologi adalah fiksasi untuk menjaga struktur asli dari sampel, dehidrasi untuk menghilangkan kandungan air dari sampel, pengeringan untuk menghilangkan kandungan cairan dari sampel, serta melapisi dengan lapisan konduktif untuk menambah konduktivitas permukaan sampel. Selain itu juga terdapat beberapa jenis mode khusus yang dapat ditambahkan pada instrumen SEM untuk pengamatan sampel biologi seperti cryo-SEM dan VP-SEM.

\section{Daftar Pustaka}

[1] Williams D.B. and Carter C.B., "Transmission Electron Microscopy - A Textbook for Materials Science", Springer, 2009.

[2] Salzer, R., Graff, A., Simon, M., \& Altmann, F., "Standard free thickness determination of thin TEM samples via backscatter electron image correlation", Microscopy and Microanalysis 15(S2), 2009, pp.340-341.

[3] Bozolla, J. J. \& Russel L., D., "Electron Microscopy: Principles and Techniques for Biologists", Jones \& Bartlett Learning, 1999. 
[4] Gusnard, D. \& Kirschner, R. H., "Cell and organelle shrinkage during preparation for scanning electron microscopy: effects of fixation, dehydration and critical point drying", Journal of microscopy, 110(1), 1977, pp.5157.

[5] Nation, J. L., "A new method using hexamethyldisilazane for preparation of soft insect tissues for scanning electron microscopy", Stain technology, 58(6), 1983, pp.347-351.

[6] Bray, D. F., Bagu, J., \& Koegler, P., "Comparison of hexamethyldisilazane (HMDS), Peldri II, and critical-point drying methods for scanning electron microscopy of biological specimens", Microscopy research and technique, 26(6), 1993, pp.489-495.
[7] Murakami, T., A revised tannin-osmium method for non-coated scanning electron microscope specimens. Archivum histologicum japonicum, 36(3), 1974, pp.189-193.

[8] Widáhn, S., \& Kindblom, L. G., "A rapid and simple method for electron microscopy of paraffin-embedded tissue", Ultrastructural Pathology, 12(1), 1988, pp.131-136.

[9] Hassan, A. N., Frank, J. F., \& Elsoda, M. "Observation of bacterial exopolysaccharide in dairy products using cryo-scanning electron microscopy", International Dairy Journal, 13(9), 2003, 755-762.

[10]Debbie Stokes, "Principles and Practice of Variable Pressure / Environmental Scanning Electron Microscopy (VP-ESEM)", John Wiley \& Sons, 2008. 